\title{
ЛІКУВАННЯ ХРОНІЧНОГО ГІПОПАРАТИРЕОЗУ У ДОРОСЛИХ: СУЧАСНІ ПОГЛЯДИ НА ДІАГНОСТИКУ І ЛІКУВАННЯ (З ОГЛЯДУ НА ОСТАННІ КЛІНІЧНІ НАСТАНОВИ ЄВРОПЕЙСЬКОЇ ТОВАРИСТВА 3 ЕНДОКРИНОЛОГІї)
}

\author{
М.С. Черенько, Крушинська 3.Г. \\ Украӥнський науково-практичний центр ендокринної хірургії, трансплантації \\ ендокринних органів і тканин, МОЗ України
}

2015 року в журналі European Journal of Endocrinology були опубліковані настанови Європейської товариства 3 ендокринології ( $Є \mathrm{TE})$ щодо лікування дорослих пацієнтів із хронічним гіпопаратиреозом. У нашій медичній спільноті дана публікація не набула широкої популярності, адже ця патологія зустрічається не так часто. Цей документ містить майже всю відому на цей час інформацію щодо даного захворювання і має стати основою для сучасного і адекватного лікування цієї когорти хворих. Особливо корисними ці настанови будуть для ендокринних хірургів і ендокринологів, які працюють 3 хворими із післяопераційним гіпопаратиреозом.

Для створення настанов було проаналізовано 1100 робіт 3 даної тематики, 3 них за дуже чіткими критеріями включення/виключення було виділено 16 досліджень, які $\epsilon$ найбільш коректно проведеними. Проте враховуючи таку, відносно невелику кількість наукових праць, і те що найбільша серія спостережень включає лише 100 пацієнтів, за критеріями доказовості більша частина рекомендацій має низьку доказовість ( $\odot \bigcirc \bigcirc)$.

у даній публікації будуть висвітлені та прокоментовані лише найбільш принципові положення цих настанов.

Гіпопаратиреоз (ГПТ) $€$ рідкісним (орфанним) ендокринним захворюванням, що проявляється низьким рівнем кальцію у крові і неадекватно низькими рівнями циркулюючого паратиреоїдного гормону (ПГ). Найчастіше у дорослих причиною даного стану $\epsilon$ операція на шиї (щитоподібній та паращитоподібних залозах). Транзиторна гіпокальціємія, що розвивається у 30-60\% хворих після тиреоїдної хірургії впродовж перших 24 годин, проходить у 60-70\% випадків протягом 4-6 тижнів. Тривалість цього стану найбільше залежить від кількості паращитоподібних залоз, які залишилися не ушкодженими.

Заданими останньогопопуляційногодослідження, яке було проведене у Данії, частота цієї патології склала 24 на 100000 населення, серед яких лише 2 особи на 100000 мають нехірургічні причини ГПт. Стандартом лікування хронічного ГПТ $є$ призначення активних аналогів вітаміну Д і препаратів кальцію, а не призначення замісної терапії гормоном, як для інших дефіцитних станів.

- Діагноз встановлюють на основі низьких рівнів кальцію і невідповідно низьких рівнів ПГ (конкретні цифри вказати неможливо, проте відомо, що за нормальної роботи паращитоподібних залоз, рівень паратгормону на тлі гіпокальціємії значно підвищується).

- Якщо етіологія захворювання невідома, бажано проведення генетичного та/або родинного скринінгу на ГПТ. (В умовах України наразі визначаємо рівні кальцію і ПГ у родичів).

- Метоюлікуваннятакиххворихєпідтриманнярівня кальцію (іонізованого або альбумін-корегованого загального кальцію) у нижній межі референтних значень або трохи нижче за умови відсутності симптомів гіпокальціємії $(\oplus \bigcirc \bigcirc \bigcirc)$. Конкретні цільові значення наразі не можуть бути встановлені, адже велике значення має індивідуальна чутливість до гіпокальціємії і переносимість лікування.

- Добова екскреція кальцію із сечею на тлі лікування має бути у межах норми (๑○○○). Так для чоловіків цей показник не має перевищувати 7,5 ммоль/добу (300 мг/добу), а для жінок - 6,25 ммоль/ добу (250 мг/добу); або до 0,1 ммоль/кг за добу (4 мг/ кг за добу) для обох статей.

- Рівні фосфору, магнію, вітаміну Д мають бути у межах норми ( $\bigcirc \bigcirc \bigcirc)$. Відомо, що низький рівень магнію у крові пригнічує синтез паратгормону i викликає «функціональний гіпопаратиреоз». Тому до встановлення діагнозу хронічного ГПТ рівень магнію має бути відновлений. Щодо вітаміну Д, то рівні 25-гідроксивітаміну Д (25OHD) у крові мають перевищувати 50 нмоль/л (20 нг/мл).

- Кальцій-фосфорний добуток має бути нижчий за 4,4 ммоль2/л2 ( $О О О)$. Цей показник, в основному, зростає за рахунок збільшення рівня фосфору 
у крові. Останнє обумовлене двома факторами: зменшенням фосфатуричного ефекту паратгормону (за рахунок зменшення його абсолютної кількості) та зростання абсорбції фосфору із кишківника (за рахунок лікування активними метаболітами вітаміну Д). Збільшення кальцій-фосфорного добутку призводить до позаскелетних відкладень солей кальцію, частіше нефрокальцинозу та катаракти.

- Лікування має бути персоналізованим i спрямованим перш за все на добре самопочуття i високу якість життя пацієнта. Загалом пацієнти із ГПТ мають нижчу якість життя, скарги на м'язову слабкість, втомлюваність, нервозність і схильність до депресії. Призначене лікування не має призводити до погіршення якості життя хворих. Також необхідно враховувати різні супутні захворювання та лікарські препарати, що можуть впливати на кальцієвий баланс у організмі (табл. 3).

- Важливе значення має своєчасне та ретельне інформування пацієнтів щодо можливих симптомів гіпо- та гіперкальціємії, а також імовірних ускладнень їхньої хвороби (сечокам'яна хвороба і ниркова недостатність, табл. 2).

- Лікування необхідне всім пацієнтам із хронічним ГПт і симптомами гіпокальціємії та/або рівнем альбумін-корегованого загального кальцію менше 2,0 ммоль/л або іонізованого кальцію менше 1,0 ммоль/л $\oplus \bigcirc \bigcirc \bigcirc)$.

- Асимптомним пацієнтам із рівнем альбумінкорегованого загального кальцію більше 2,0 ммоль/л або іонізованого кальцію більше 1,0 ммоль/л, але нижче нижньої межі норми, лікування може бути запропоноване з метою оцінки, чи не покращиться їх якість життя (๑О○О).

- Терапією першого ряду є призначення активних аналогів вітаміну Д і препаратів кальцію у декілька прийомів за день (Ф○ОО). Якщо активні форми вітаміну Д не доступні, можна призначати кальциферол (бажано холекальциферол). Необхідна добова доза елементарного кальцію має складати 800-2000 мг/добу і може бути забезпечена як надходженнями із продуктами харчування (в основному, молочні продукти), так і препаратами кальцію. Абсорбційна здатність кишківника складає приблизно 500 мг, тобто збільшення разової дози не призведе до зростання всмоктування. Тому добова доза кальцію має бути розподілена на декілька менших доз впродовж доби. Треба відокремлювати у часі прийом препаратів кальцію і L-тироксину, враховуючи значну інтерференцію між ними. Найдешевшою i найрозповсюдженішою 3-поміж солей кальцію $€$ кальцію карбонат, який, однак, потребує кислотного середовища для покращення всмоктування, а отже має прийматися під час їжі. Солі кальцію цитрату мають призначатися пацієнтам 3 ахлоргідрією та тим, хто приймає інгібітори протонної помпи. Високе надходження кальцію із їжею та препаратами може зменшувати потребу у вітаміні Д.

- Титрування дози препаратів вітаміну Д має тривати допоки не зникнуть симптоми гіпокальціємії, а рівень кальцію не досягне цільових значень $(\oplus \bigcirc \bigcirc \bigcirc)$.

- Доза препаратів вітаміну Д має становити 400800 МО на день у хворих, що отримують лікування активними метаболітами вітаміну Д (ФО○О). Наразі не існує досліджень, які порівнювали б ефективність різних препаратів вітаміну Д у цієї групи хворих, проте найбільший ефект щодо збільшення рівня кальцію має кальцитріол (табл. 1). Якщо рівні кальцію не $\epsilon$ оптимальними, доза активних метаболітів поступово титрується (на 0,5 мкг і 0,25 мкг на добу для альфакальцидолу і кальцитріолу відповідно, 1 раз у 2-3 дні). Якщо пацієнт отримує високі дози кальциферолу, то ефект збільшення дози оцінюють через 2-3 міс.

- У пацієнтів із гіперкальціурією рекомендовано зменшити дозу препаратів кальцію, застосовувати низькосольову дієту, а також тіазидні діуретики $(\oplus \bigcirc \bigcirc \bigcirc)$. У пацієнтів із сечокам'яною хворобою необхідна ретельна оцінка факторів ризику та застосування лікування згідно міжнародних настанов, що існують. Гіпокальціуричний ефект тіазидних діуретиків має дозозалежний характер, тому дози, які призначаються, є достатньо високими (наприклад, 50 мг гідрохлортіазида 2 рази на день).

- Упацієнтів із гіперфосфатемієюта/абозбільшеним кальцій-фосфорним добутком необхідна корекція дієти (із зменшенням надходження фосфору) та доз препаратів вітаміну Д і кальцію (кальцій виступає як фосфатзберігаючий середник).

- Рутинне призначення паратгормону або його аналогів не рекомендоване. Препарати паратиреоїдного гормону введені на ринок США з 2015 року, проте ще не достатньо вивчені їх віддалені ефекти. Враховуючи їх відсутність на ринку України, у даній публікації ми не будемо зупинятися на особливостях їх застосування.

- Моніторинг рівнів кальцію, магнію та креатиніну (швидкості клубочкової фільтрації), а також симптомів гіпо- або гіперкальціємії необхідно виконувати кожні 3-6 місяців. Після зміни доз 
препаратів контроль необхідно проводити наступного тижня або через тиждень. Рівень кальціурії має визначатися регулярно, принаймні 1 раз на 1-2 роки (рис. 1).

- Ультразвукове дослідження нирок необхідно проводити у разі наявності симптомів сечокам'яної хвороби, або у разі зростання рівня креатиніну. Регулярне виконання остеоденситометрії не рекомендоване.

- у пацієнтів із аутосомно-домінантною гіпокальціємією моніторинг необхідно проводити частіше, адже ризик виникнення гіперкальціурії та сечокам'яної хвороби у таких пацієнтів вищий. Також частіше вони страждають на катаракту та ішемічну хворобу серця.

- У вагітних жінок та жінок у період лактації підходи до лікування такі самі. Проте моніторинг рівня кальцію необхідно проводити кожні 2-3 тижні весь цей час, а для оцінки використовувати краще рівень іонізованого кальцію. Поганий контроль за рівнем кальцію крові може призвести до спонтанного переривання вагітності, передчасних пологів і неонатальної смерті. Материнська гіпокальціємія може призвести до порушень розвитку скелету (деформації, переломи), компенсаторного гіперпаратиреозу і гіперплазії паращитоподібних залоз, а також респіраторного дистрес-синдрому, гіпотрофії та гіпотонії у новонароджених. У той же час гіперкальціємія у матері може призвести до пригнічення паращитоподібних залоз у дитини із розвитком неонатальних гіпокальціємій.

Підсумки усіх настанов зображені на рисунку 1. Ця схема $\epsilon$ доволі зручною та ії легко застосувати в умовах нашої країни. За умови виконання усіх терапевтичних нюансів щодо хворих із хронічним гіпопаратиреозом, якість і тривалість життя таких пацієнтів має значно зрости.

Табличя 1

Препарати вітаміну Д у лікуванні хронічного ГПт.

\begin{tabular}{|c|c|c|c|}
\hline Препарат & Доза & $\begin{array}{c}\text { Час до початку дії } \\
\text { (дні) }\end{array}$ & $\begin{array}{c}\text { Час до припинення } \\
\text { дії (дні) }\end{array}$ \\
\hline Кальцитріол & $\begin{array}{c}\text { 0,25-2,0 мкг 1-2 рази } \\
\text { на день }\end{array}$ & $1-2$ & $2-3$ \\
\hline Альфакальцидол & $\begin{array}{c}\text { 0,5-4,0 мкг } 1 \text { раз на } \\
\text { день }\end{array}$ & $1-2$ & $5-7$ \\
\hline Дигідротахістерол & $\begin{array}{c}\text { 0,3-1,0 мг } 1 \text { раз на } \\
\text { день }\end{array}$ & $4-7$ & $7-21$ \\
\hline Ергокальциферол & \multirow{2}{*}{$\begin{array}{c}25000-200000 \text { MO } \\
1 \text { раз на день }\end{array}$} & \multirow{2}{*}{$10-14$} & \multirow{2}{*}{$14-75$} \\
\hline Холекальциферол & & & \\
\hline
\end{tabular}

Симптоми гіпо- та гіперкальціємії, про які необхідно попередити пацієнта.

\begin{tabular}{|l|c|c|}
\hline \multicolumn{1}{|c|}{ Органи і системи } & Гіпокальціємія & Гіперкальціємія \\
\hline Центральна нервова система & $\begin{array}{c}\text { депресія, дратівливість, дезорієнтація, } \\
\text { сплутаність свідомості, судоми }\end{array}$ & $\begin{array}{c}\text { слабкість, головний біль, } \\
\text { головокружіння, дезорієнтація, } \\
\text { сплутаність свідомості, погіршення } \\
\text { пам'яті, зниження концентрації }\end{array}$ \\
\hline М'язи & парестезії пальців ніг та рук, судоми, \\
спазми & м'язова слабкість \\
\hline Серцево-судинна система & $\begin{array}{c}\text { сповільнення, прискорення або } \\
\text { нестабільність серцевого ритму, } \\
\text { симптоми застійної серцевої } \\
\text { недостатності }\end{array}$ & $\begin{array}{c}\text { сповільнення, прискорення або } \\
\text { нестабільність серцевого ритму, } \\
\text { артеріальна гіпертензія }\end{array}$ \\
\hline
\end{tabular}




\begin{tabular}{|l|r|r|}
\hline Шлунково-кишковий тракт & кишкові спазми & $\begin{array}{c}\text { зниження апетиту, нудота, блювання, } \\
\text { болі у животі, закрепи }\end{array}$ \\
\hline Видільна система & & поліурія, сухість у роті, спрага \\
\hline Респіраторна система & $\begin{array}{c}\text { задишка, хрипи, відчуття стиснення у } \\
\text { горлі }\end{array}$ & \\
\hline
\end{tabular}

Ліки та захворювання, які впливають на обмін кальцію і вимагають корекції терапії у пацієнтів із Гпт.

\begin{tabular}{|c|c|c|c|}
\hline Ліки та захворювання & Механізм дії & $\begin{array}{l}\text { Можливі ефекти } \\
\text { у хворих із ГПт }\end{array}$ & Діï \\
\hline Петльові діуретики & $\begin{array}{l}\text { Підвищують втрати } \\
\text { кальцію із сечею }\end{array}$ & $\begin{array}{l}\text { Можуть погіршувати } \\
\text { гіперкальціурію та } \\
\text { гіпокальціємію }\end{array}$ & $\begin{array}{l}\text { По можливості не } \\
\text { застосовувати }\end{array}$ \\
\hline Тіазидні діуретики & $\begin{array}{l}\text { Зменшують втрати } \\
\text { кальцію із сечею }\end{array}$ & $\begin{array}{l}\text { Можуть викликати } \\
\text { гіперкальціємію }\end{array}$ & $\begin{array}{c}\text { Можуть застосовуватися } \\
\text { за необхідності }\end{array}$ \\
\hline Системні стероїди & $\begin{array}{c}\text { Підвищують втрати } \\
\text { кальцію із сечею, } \\
\text { зменшують абсорбцію } \\
\text { кальцію у кишківнику }\end{array}$ & $\begin{array}{l}\text { Можуть викликати } \\
\text { гіпокальціємію }\end{array}$ & $\begin{array}{c}\text { По можливості не } \\
\text { застосовувати }\end{array}$ \\
\hline Антирезорбтивні препарати & $\begin{array}{l}\text { Знижують кістковий } \\
\text { метаболізм }\end{array}$ & $\begin{array}{l}\text { Можуть викликати } \\
\text { гіпокальціємію }\end{array}$ & Частіше непотрібні \\
\hline Інгібітори протонної помпи & $\begin{array}{c}\text { Можуть викликати гіпо- } \\
\text { магніємію }\end{array}$ & $\begin{array}{c}\text { Можуть знижувати рі- } \\
\text { вень кальцію у крові і ви- } \\
\text { кликати симптоми схожі } \\
\text { на прояви гіпокальціємії } \\
\end{array}$ & $\begin{array}{c}\text { По можливості не за- } \\
\text { стосовувати, у разі } \\
\text { застосування призначати } \\
\text { препарати магнію } \\
\end{array}$ \\
\hline $\begin{array}{r}\text { Хіміотерапія (цисплатина, } \\
\text { 5-фторурацил, лейковорин) }\end{array}$ & $\begin{array}{c}\text { Можуть викликати гіпо- } \\
\text { магніємію }\end{array}$ & $\begin{array}{c}\text { Можуть знижувати рі- } \\
\text { вень кальцію у крові і ви- } \\
\text { кликати симптоми схожі } \\
\text { на прояви гіпокальціємії }\end{array}$ & $\begin{array}{c}\text { У разі застосування при- } \\
\text { значати препарати магнію }\end{array}$ \\
\hline $\begin{array}{l}\text { Серцеві глікозиди (ди- } \\
\text { гоксин) }\end{array}$ & $\begin{array}{c}\text { Гіперкальціємія може } \\
\text { потенціювати токсичність } \\
\text { дигоксину, гіпокальціємія - } \\
\text { знижувати ефективність цих } \\
\text { препаратів }\end{array}$ & Аритмії & $\begin{array}{c}\text { По можливості не засто- } \\
\text { совувати, у разі застосу- } \\
\text { вання - ретельне спосте- } \\
\text { реження кардіологом }\end{array}$ \\
\hline $\begin{array}{l}\text { Діарея, гастро-інтестинальні } \\
\text { хвороби }\end{array}$ & $\begin{array}{c}\text { Можуть знижувати абсор- } \\
\text { бцію кальцію і вітаміну Ду } \\
\text { кишківнику }\end{array}$ & $\begin{array}{c}\text { Можуть викликати гіпо- } \\
\text { кальціємію }\end{array}$ & $\begin{array}{c}\text { Ретельне моніторування } \\
\text { рівнів кальцію у крові, } \\
\text { корекція доз препаратів } \\
\text { кальцію і вітаміну Д } \\
\end{array}$ \\
\hline $\begin{array}{l}\text { Зміни кислотно-лужного } \\
\text { балансу }\end{array}$ & $\begin{array}{c}\text { Здатність кальцію зв'я- } \\
\text { зуватися із білками плазми } \\
\text { значно залежить від рН } \\
\text { крові - тільки вільні фракції } \\
\epsilon \text { фізіологічно активними }\end{array}$ & $\begin{array}{c}\text { Корекція метаболічного } \\
\text { ацидозу може викликати } \\
\text { гіпокальціємію, корекція } \\
\text { метаболічного алкалозу } \\
\text { може викликати гіпер- } \\
\text { кальціємію } \\
\end{array}$ & $\begin{array}{l}\text { Ретельне моніторування } \\
\text { рівнів кальцію у крові, } \\
\text { корекція доз препаратів } \\
\text { кальцію і вітаміну Д }\end{array}$ \\
\hline Іммобілізація & $\begin{array}{c}\text { Підвищення кісткової } \\
\text { резорбції. У здорових людей } \\
\text { паратгормон і 1,25-ди- } \\
\text { гідроксивітамін Д будуть } \\
\text { пригнічені }\end{array}$ & $\begin{array}{c}\text { Може викликати гіпер- } \\
\text { кальціємію }\end{array}$ & $\begin{array}{l}\text { Ретельне моніторування } \\
\text { рівнів кальцію у крові, } \\
\text { корекція доз препаратів } \\
\text { кальцію і вітаміну Д }\end{array}$ \\
\hline
\end{tabular}




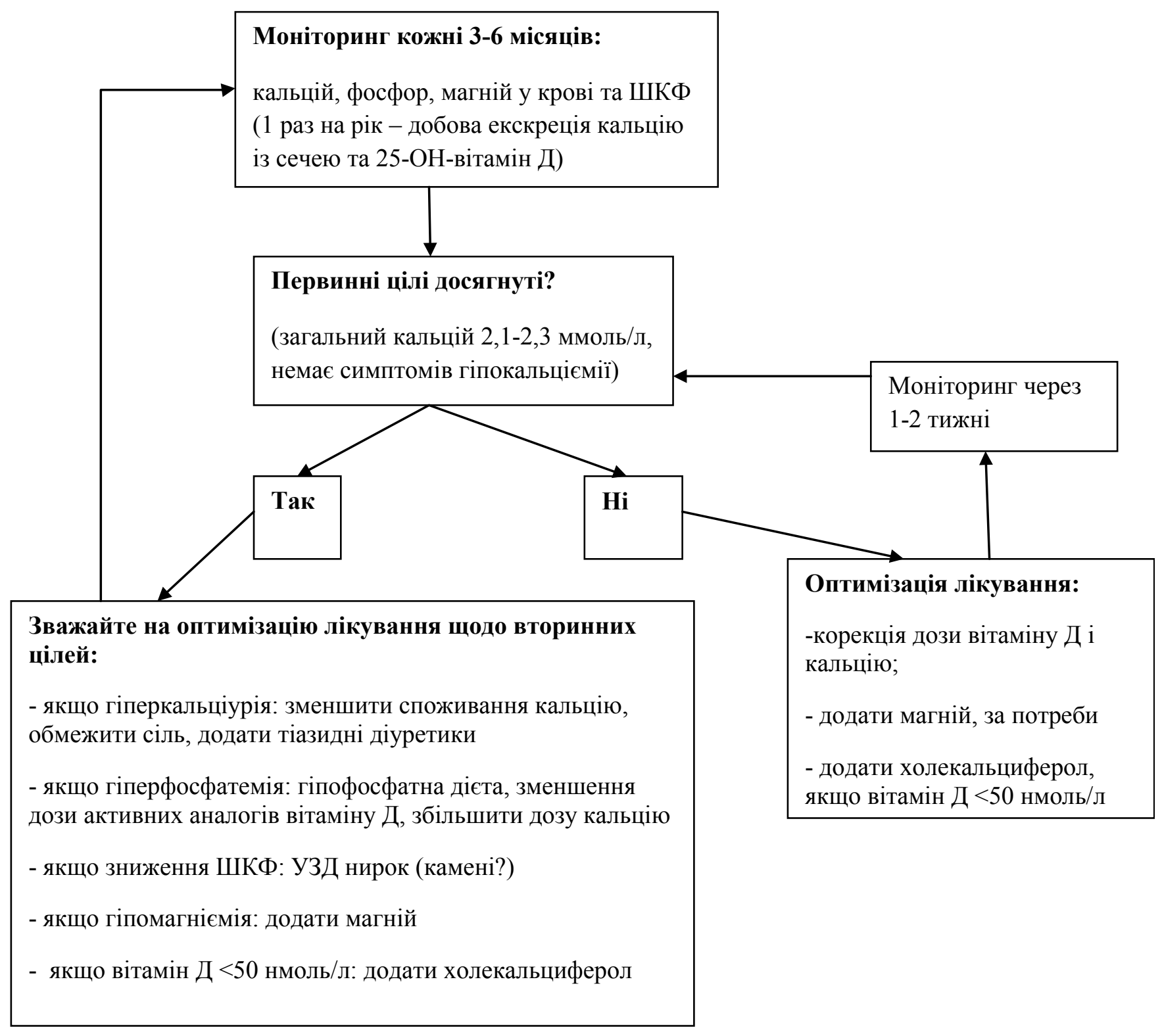

Puc. 1. Моніторинг і лікування хворих на хронічний гіпопаратиреоз.

\section{ЛITEPATУРA}

1. European Society of Endocrinology Clinical Guideline:Treatment of chronic hypoparathyroidism in adults [Text] / J. Bollerslev, L. Rejnmark, C. Marcocci [et. al] // Eur. J. Endocrinol. - 2015. - V. 173. - N. 2. - P. G1-G20.

\section{REFERENCES}

1. Bollerslev J, Rejnmark L, Marcocci C, Shoback DM, Sitges-Serra A, van Biesen W, Dekkers OM; European Society of Endocrinology. European Society of Endocrinology Clinical Guideline: Treatment of chronic hypoparathyroidism in adults. Eur J Endocrinol. 2015 Aug;173(2):G1-20. doi: 10.1530/ EJE-15-0628.

Дата надходження до редакції 24.02.2016 p. 